\title{
Assessment of Prior Learning in Adult Vocational Education and Training
}

\author{
Vibe Aarkrog* \\ Aarhus University \\ Department of Education \\ Tuborgvej 164, 2400 Copenhagen N.V. Denmark \\ E-mail:viaa@edu.au.dk

\section{Bjarne Wahlgren} \\ Aarhus University \\ Department of Education \\ Tuborgvej 164, 2400 Copenhagen N.V. Denmark \\ E-mail: Wahlgren@edu.au.dk \\ * Corresponding author
}

\begin{abstract}
The article deals about the results of a study of school-based Assessment of Prior Learning of adults who have enrolled as students in a VET college in order to qualify for occupations as skilled workers. Based on examples of VET teachers' methods for assessing the students' prior learning in the programs for gastronomes, respectively child care assistants the article discusses two issues in relation to Assessment of Prior Learing: the encounter of practical experience and school-based knowledge and the validity and reliability of the assessment procedures. Through focusing on the students' knowing that and knowing why the assessment is based on a scholastic perception of the students' needs for training, reflecting one of the most important challenges in Assessment of Prior Learning: how can practical experience be transformed into credits for the knowledge parts of the programs? The study shows that by combining several Assessment of Prior Learning methods and comparing the teachers' assessments the teachers respond to the issues of validity and reliability. However, validity and reliability might be even further strengthened, if the competencies are well defined, if the education system is aware of securing a reasonable balance between knowing how, knowing that, and knowing why, and if the teachers are adequately trained for the assessment procedures.
\end{abstract}

Keywords: adults, skilled qualification, school-based assessment of prior learning, knowing how, knowing that, assessor qualifications

\section{Bibliographical notes:}

Vibe Aarkrog PhD is associate professor in VET pedagogy at the Department of Education, Aarhus University, Denmark. Her research focuses on the interrelation 
between the school-based and workplace-based parts of dual programs and on transfer of training from school to workplace and vice versa.

Bjarne Wahlgren $\mathrm{PhD}$ is professor at the Department of Education at Aarhus University, Denmark, and director for The National Centre of Competence Development. His research focuses on transfer of training, assessment of competences, dropout and teacher training in adult and vocational education. 


\section{Introduction}

Based on an empirical study of methods for assessing prior learning (APL) ${ }^{1}$ in two VET-programs, the purpose of the article is to discuss the advantages and disadvantages of school-based APL. The two VET programs train for skilled positions as gastronomes (chefs), respectively child care assistants, and APL is the first step in qualifying adults, who have worked within these fields for a number of years and want to enrol as students to obtain the formal qualification. Based on the assessment of each student's prior learning a personal education and training plan will be drafted, specifying the training that the student needs in order to obtain the qualification as skilled worker. This paper solely focuses on APL.

APL has been studied internationally in various settings and to a great extent in comparative studies based on descriptions of the organization of APL in different countries (Andersson and Stenlund, 2012; Harris and Breier et al., 2011). Most of the studies focus on the organizational setting and the political background for APL, e.g. in relation to lifelong learning, employability, and in relation to economic, social and cultural purposes (Andersen and Laugesen, 2012; Halttunen et al., 2014). Only few studies have focused on the assessment process.

In this article we focus on the assessment process including the construction of assessment instruments. The article exemplifies how prior learning can be assessed against the required competencies for a skilled position. The assessment process takes place in vocational colleges. Consequently the article provides knowledge about school-based APL.

\section{Theoretical background}

"Prior learning" is defined in different ways (Billett et al., 2014). We define prior learning as the sum of all the individual's competences i.e. competences achieved by formal learning, non-formal learning and informal learning (CEDEFOP, 2009; Colardyn and Bjørnåvold, 2004; EuropeanCouncil, 2012). Prior learning includes school based knowledge as well as practical experiences. In this article we use the European Council's definition of competence:

"Competence means the proven ability to use knowledge, skills and personal, social and or methodological abilities, in work or study situations and in professional and personal development." (EuropeanCouncil, 2008)

According to the quotation, competence is a proven ability in a concrete situation in a more specific area. A person is not competent or has competences in general. Rather competences must be referred to specific contexts. In this article the context is the curriculum of each the VET-programs which outlines the competences that qualify for positions as skilled workers within the specific industry.

Pivotal in the term competence is the term 'use', which is the ability to apply your skills, signifying that APL not only includes the individual's knowledge and

1 In the literature the concepts used to assess prior learning include e.g. recognition of priorlearning (RPL), accreditation of prior experiential learning (APEL), prior learning assessment (PLA), prior learning assessment and recognition (PLAR) and validation of prior learning (VPL)(Per Andersson et al., 2013, p. 405). In this article assessment of prior learning (APL) is used to describe the assessment process and the outcome of the assessment. 
skills. APL also includes a focus on the individual's ability to perform in specific situations.

An individual's prior learning is assessed - like any other competence - in relation to some standard. A standard could be the demands that are inherent in the ability to solve tasks within specific fields, e.g. the sufficient competencies to be a bricklayer or a carpenter, a doctor or a lawyer. Often such competencies are formalised in qualification demands. Whether one is qualified to work (professionally) as a bricklayer, carpenter, doctor, or lawyer depends on a formal qualification.

Consequently, if an individual's prior learning is to be measured against the demands of performing in a position, a job, or an occupation you will (usually) assess to what extent the individual's competences (prior learning) match the formal qualifications achieved through the educational program that qualify for the current position, job etc.

According to Bohlinger, using formal qualifications as the yardstick raises specific problems:

"The main criterion for distinguishing qualifications and competences is based on the assumption that qualifications are knowledge and skills that can be objectively described and are functional. In contrast, the concept of competence encompasses many different aspects, among them skills and abilities, but also aspects of individual personality, motivation and volition" (Bohlinger, 2013).

Therefore the challenge in APL is to compare the students' competences with the competencies in the national curriculum for the specific VET-program and to translate the students' competences into these national competencies.

Cooper and Harris address this discussion in relation to higher education and point out:

"while knowledge gained from life and work experiences may be as valuable as formal, academic knowledge, these two forms of knowledge are not the same" (Cooper and Harris, 2013).

The same topic - i.e. matching individual experiences with institutionalized learning outcome descriptions - has been addressed by Pokorny (Pokorny, 2011). A central question is: should the person's competences be identical with or equivalent to the contents and levels of the learning outcome specifications in the current educational program? (Aarkrog and Wahlgren, 2013).

In relation to a given educational standard, APL raises a number of theoretical issues (Andersson and Harris). One vital issue is the traditional relation between "knowing how" and "knowing that" (Ryle, 1949). A great amount of a person's prior learning consists of knowing how while the educational standard is more based on knowing that.

Another issue is that competence is related to the context and consequently it is essential to understand

"how different forms of knowledge are 're-contextualised' as people move between sites of learning and practice in work ..." (Evans et al., 2011).

A third issue is that the precondition for assessing prior learning is that the competence is demonstrable. However, much of the workers' actual competence is based on tacit knowledge? (Polanyi, 1966) When the workers cannot articulate their competences, it is difficult to make an adequate assessment (Watkins et al., 2014). 
A fourth and central issue concerns reliability and validity (Andersson, 2006). In a study of the reliability of APL in higher education, Stenlund compares different results of the assessment process over time and among different evaluators. She concludes that the reliability is rather low, even though the criteria for assessment are rather specific. She concludes

"that there is a need to take validity issues in APL seriously" (Stenlund, 2011).

In an empirical study of the translation of the heterogeneous skills among qualified immigrants who want to be integrated into the labour market, Diedrich highlights the challenge of understanding complicated and comprehensive skills (Diedrich, 2013a and 2013b). Starr-Glass discusses validity and points out that the question is not only whether a certain performance resembles a certain course, but also whether the recognition of the candidate's work leads to a successful study and eventually to a qualification (Starr-Glass, 2012); later in this article this is referred to as predictive validity.

Summing up, research points to a number of issues and problems in relation to assessing students' prior learning against the competencies required to obtain the formal qualification. A recurrent issue concerns the validity of the assessment. A main challenge in relation to validity is how to transform the results from the assessment of the practical experiences (mainly based on knowing how) to the standards of curriculum-based knowledge (to a great extent based on knowing that).

\section{Empirical Data}

The assessment of the students in this project is situated at two different vocational colleges, one technical college that trains gastronomes and one social and health college that trains child care assistants. During the research period 26 students, i.e. six gastronomes and 20 assistants, applied for assessment. All the students passed the assessment process, however with different results.

The data in this study has been based on observations and interviews and include:

- Observations of the assessment of the students. The observations focus on how the students are supported in describing and/or demonstrating their skills and competences

- Interviews with the teachers who assess the students: the purpose is to learn about the teachers' arguments for and considerations in relation to assessing the students' prior learning

- Analysis of tests that were used in the assessment process

The researchers have observed seven situations of the students' practical performances, i.e. three observations in the program for gastronomes and four observations in the program for child care assistants.

Based on the observations the teachers were interviewed about their impressions of the students' prior learning and their reflections on how they assess the students' competences. The teachers were asked to outline their criteria for validation: what did they focus on when observing the student's performance? All together ten teachers were interviewed. The interviews were semi-structured with open ended questions. The interviews were recorded and "vital sentences" were written down. 
"Vital sentences" are sentences that put light on the criteria the teachers use for deciding whether the student possesses the competency or not. All the teachers were asked: how can you tell whether or not the student possesses the particular competency?

\section{The skilled competency profile}

The qualification for a skilled position includes a specific set of competencies. These competencies are described as learning outcomes in the national curriculum (see examples in tables 1 and 2). The competencies deal about accomplishing a number of tasks or performing in various situations, e.g.: you need to select and work with materials; you should be able to work in teams when solving professional and practical tasks, or you should be able to communicate professionally within the field.

To fulfil the skilled job requirements the individual must have knowledge of professional terms about the field (knowing-that) and routine in solving these tasks (knowing-how). He must be able to transfer knowledge and skills from one situation to another and to perceive similarities between situations (knowing why). So a skilled worker's performance includes a complex combination of know-how, knowthat, and know-why and an ability to apply these forms of knowledge in diverse contexts.

Consequently, to assess whether the individual possesses the sufficient competences to be entitled to a formal VET qualification, the assessment instrument should be designed to assess knowing that, knowing how and knowing why in a way that shows the individual's competences unfolded in real work situations. Below follow two examples of assessment procedures.

\section{Assessment of gastronome competencies}

The students, who want to join the program for gastronome (chef), typically work in restaurants, inns, kitchens e.g. canteens, cafés or in catering.

The learning outcome descriptions in the national curriculum for the gastronome program include 21 competencies (Table 1). The competencies are described in terms of behaviour and with increasing complexity. The simplest competencies include being able to evaluate ingredients (competency 1) and to be able to use the correct ingredients (competency 2). The more complex competencies include e.g. being able to compose and cook party menus, calculate cost of ingredients, and draw up calculations individually with increasing routine (competency 19), compose, draw up recipes and cook various courses from seasonal ingredients and increasing creativity (competency 20), and accomplish á la carte as well as party orderings (competency 21). The required competencies are mainly technical competencies. However, the competencies also include personal competencies e.g. competency 8: show creativity as well as initiative and ability for learning and take responsibility and social competencies e.g. being able to work in teams and contribute to developing the work (competency 7). Furthermore general competencies are required, e.g. language (English) and arithmetic (calculations). The competencies must be comprehensive (including different kinds of "kitchens") and transferable, in order to qualify the student to work in the most common types of businesses (competency 6).

It is important to notice that all 21 competencies are related to activities and actions. The competencies all describe tasks that the student should be able to accomplish or situations in which the student should be able to perform. The compe- 
tencies are related to knowing how. However the competencies include both knowing that and knowing why. If the student should be able to take into consideration hygiene, environment, work environment, safety at work (competency 3 ), he/she must have knowledge about these matters, i.e. knowing that. Likewise, if the student should be able to use the correct ingredients he must know something about the ingredients. And if he should be able to explain food culture to the guests, he must know something about food culture. Furthermore the students should be able to reflect on their performance. They must be able to argue for their performance; they must know why. When the students should be aware of the impact of each employee's function and organisational position on the company's daily business ... (competency 16) they should be able to argue for this relation. And when the students "compose" and "calculate" (competency 19) they should be able to argue for these compositions and calculations. The students should be able to use and demonstrate knowing why. Consequently, the assessment method must be able to measure whether the student is able to perform in an adequate way as well as whether the student has the appropriate amount of knowing that and knowing why.

\section{Table 1: Competencies for the program at the gastronome (chef) education}

To reach professional level the student must be able to:

1. evaluate ingredients

2. use the correct ingredients, materials, methods, tools, and equipment in connection with a given task

3. perform work in consideration of hygiene, environment, work environment, safety at work, time, economy and quality

4. prepare fast food and heat, lukewarm, and cold dishes based on correct basic cooking methods and in accordance with the rules about hygiene and the company's own-check for serving in self-catering restaurants, canteens, cafés, hotels, restaurants, and takeaways

5. plan, prepare, and arrange menus in accordance with principles of nutrition and accomplish nutrition calculations in accordance with current law

6. adjusting to work and cooperation in the kitchens of the most common types of business and keep up with trends

7. work in teams and contribute to developing the work

8. show creativity as well as initiative and ability for learning and take responsibility

9. be flexible and cooperate with colleagues, customers, and other stakeholders, regardless of ethnic background

10. express oneself orally, consider and understand ideas and points of view

11. individually or as part of a team analyse and solve professional problems

12. recognise strengths and weaknesses of personal learning potentials and motivation as basis for lifelong learning

13. serve the company's customers and guests respecting their nationalities

14. be co-responsible that the guests feel welcome and have a good experience

15. serve and explain menus and food culture to guests and use common professional texts in English

16. be aware of the impact of each employee's function and organisational position on the company's daily business, innovation, and profitability, and contribute to a pleasant work environment

17. select, describe, purchase, quality assess, and categorise commonly used ingredients and semi-manufacture

18. prepare, cook, and arrange the kitchen's basic repertoire

19. compose and cook party menus, calculate cost of ingredients, and draw up calculations individual and with increasing routine

20. compose, draw up recipes, and cook various courses from seasonal ingredients with increasing creativity

21. accomplish à la carte as well as party orderings 


\subsection{How is the students' prior learning being assessed?}

In practice the assessment instrument consists of a preliminary interview with the student, a "theoretical" test, and the accomplishment of a practical task. The assessment of the student's prior learning takes two days for gastronomes.

The preliminary interview was based on the students' documented written experience at work and their previous education. In the interview the degree and the width of the student's experience and personal and social competences was clarified. The students were asked about their previous experiences with the occupation, in which institutions they had worked - and for how long, and what kinds of professional activities they had been engaged in. They were asked about their technical, social, personal and general competencies. And they were asked to describe the degree of self-dependence, flexibility and responsibility they have had in these jobs. The framework for the interviews consisted of the competencies in the national curriculum (Table 1).

According to our observations the interview gave a preliminary impression of the individual student's competence profile and how comprehensive and solid the competences were. The conclusion could e.g. be: "the student has knowledge about nutrition, a good overall understanding of the content of the needed competences, and the ability for innovative thinking. The student lacks experience in á la carte, knowledge of professional terms, and theoretical knowledge".

In the theoretical test the depth and comprehensiveness of the students' knowledge were assessed through sixty questions. The questions dealt with "the way to do things" (knowing how), knowledge of professional terms (knowing that), and with the arguments for the current performance (knowing why). The concrete questions about knowledge could e.g. be: "Which is the largest dear in Denmark?" or "What is a capon?" More specific questions about professional terms could e.g. be: "What does it mean to braise?" Question about know-how could e.g. be: "Describe how to cook a classical Wiener Schnitzel with garniture" or "What does it mean to sauté?" An example of a question on knowing why could be: "Why is it important that the potatoes are the same size when you boil them?" The sixty questions were organised in three categories according to the degree of their difficulty in order to assess the level of the students' knowledge. All the questions were related to and derived from the 21 required competencies.

In the practical task the students were asked to prepare three dishes from a number of ingredients and a recipe. The first two dishes, veal fricassee and pineapple mousse were selected by the teachers. The third dish was chosen by the individual student to ensure that the student had the opportunity to prepare a dish with which he or she was familiar. The idea is that the opportunity for choosing your own dish will avoid preference to specific kinds of experiences.

During the three hours of preparation the teachers evaluate the student. The practical task is chosen and planned in a way that demonstrates whether or not the student possesses specific competencies, e.g. use and preparation of the ingredients in accordance with hygienic rules, understanding of and reliance on the recipe or routine in preparing meals and awareness of the quality of the result. Do the students handle vegetables together with meat? Do they put the cream back in the fridge immediately upon use? Do they wash their hands properly? These are examples about hygiene-clues. Alongside the students' preparation of the dishes the teachers asked the students about the process and their arguments for their actions and performance. 
Based on an overall evaluation of the preliminary interviews and the students' performances in the theoretical test as well as in the practical tasks, the teachers conclude to what extent the individual student possesses the 21 competencies in the national curriculum. Some of the competencies are closely related to knowledge about the process and the student's performance (e.g. competencies 1-5) and seem relatively easy to assess. More challenging are competencies including social dimensions such as cooperation (e.g. competencies 6 and 9), personal dimensions such as handling a hard time pressure, or communicative competencies (e.g. competency 15). These competencies are assessed in the interview where the students are specifically asked about their experiences in relation to cooperation and personal performance. Some of the assessments are based partly of the students' explanations, partly on the teachers' interpretations of these explanations.

In conclusion: the interview assesses the content and amount of the students' work life experiences, including whether the student has the necessary personal and social competences. The practical task assesses the level of knowing how, i.e. how the student performs in a realistic situation. The practical task confirms or rejects the information giving in the interview. The written test assesses the amount of knowing that and knowing why which is necessary for the skilled position. Thus it is the combination of different assessment methods that secures a valid assessment.

Based on the assessment of what the unskilled worker is able to and what he or she lacks in relation to a formal qualification the teachers will draft an individual educational plan which includes the courses and exams that the individual student should complete in order to obtain the skilled qualification.

\subsection{Assessment of child care assistance competencies}

The students, who enrol in the program for childcare assistants, typically work in child nurseries or kindergartens. In this program APL combines practical task solving with student interviews and group discussions.

The competencies included in the curriculum of the VET-program for child care assistants have been outlined in table 2 .

The competencies all describe tasks that the student should be able to accomplish or situations in which the student should be able to perform, e.g. the student should be able to accomplish pedagogical activities (competency 1), stimulate the individual's language (competency 5) and be able to act in ways that resolve conflicts and prevent violence (competency 10).

As in the gastronome program the child care assistant program includes social competencies e.g. competency 1: Independently or in cooperation..., competency 6: Participate in a focused and developing communication and competency 9: Alone or in cooperation with others..., plan, execute, reflect on and develop... and personal competencies as in competency 10: independently act in ways that resolve conflicts...

The competencies include knowledge, e.g. knowledge about the target group (competency 3) and skills, e.g. Employ ICT for retrieval of information (competency $11)$. 


\section{Table 2: Competencies for the child care assistant program}

To reach professional level the student must be able to:

1. independently or in cooperation argue for and accomplish pedagogical processes that can include agreements on action plans and/or curriculums

2. independently or in cooperation develop, plan, accomplish, and evaluate physical, musical, aesthetic, cultural, and practical activities with children, youngsters, and adults

3. based on knowledge of the target group's physical and motoric skills motivate for enhancing the individual's pleasure for motion, sports and sensual experiences

4. promote health and prevent disease in working with children, youngsters, and adults, including preventing institutional infections

5. stimulate the individual's language and ability for expression either by own means or through means of communication

6. participate in a focused and developing communication which supports appreciative relations

7. mediate decisions that are significant for the citizen and his/her relatives and in accordance provide the necessary support and guidance

8. through respect for the individual's resources, conditions and ways of life, and autonomy, guide children, youngsters, adults, and their relatives in applying state, regional, community, and private services

9. alone and in cooperation with others and in accordance with the current rules and legislation within the occupation, plan, execute, reflect on and develop work practice based on the psychical and physical work environment

10. independently act in ways that resolve conflicts and prevent violence and participate in developing the workplace so that prevention of violence is a mutual responsibility for management and employees

11.employ ICT for retrieval of information, communication, cooperation, planning of work, professional disseminations and documentation of own practice

APL focuses on the students' knowledge, skills and competences. However, in the assessment process particular focus is on the students' width and depth of knowledge, the categories being: knowing how, knowing that and knowing why. All 11 competencies involve knowing how, i.e. knowledge about how to perform and solve tasks. In a number of competencies knowing how is combined with knowing that e.g. in competency 3: Based on knowledge of the target group's physical and motoric skills... Likewise the student should have knowledge about hygiene and health in competency 4, and in competency 9 the student should know the relevant legislation: ... and in accordance with the current rules and legislation within the occupation... Thus the students' actions and performances should be based on their knowledge about specific matters.

Furthermore in some of the competencies knowing how is combined with the student's ability to argue for her performance or even reflect on her performance e.g. independently or in cooperation ague for and accomplish pedagogical processes (competency 1) or: ... in accordance with the current rules and legislation within the occupation, plan, execute, reflect on and develop work practice (competency 9). Thus some of the competencies are relatively more complex as they include knowing why.

In some of the competencies these forms of knowledge will be intertwined as in competency 1: independently or in cooperation ague for and accomplish pedagogical processes that can include agreements on action plans and/or curriculums. 


\subsubsection{How is the students' prior learning assessed?}

In order to capture the students' various competencies, skills and three forms of knowledge, knowing how, knowing that and knowing why, the assessment includes practical performance, questioning, discussions, and individual interviews. According to the teachers, who assess the students, the 11 competencies above are too broad and complicated to enable a precise assessment. Therefore the teachers have broken the competencies into targets that the students should obtain either through training in specific subjects e.g. the subjects social science, psychology and chemistry or through practical training. Breaking the competencies into targets reinforce a schoolbased assessment, as the targets refer to school subjects and only indirectly to competencies.

\subsubsection{Assessment based on practical performance}

The assessment of the students' competences is typically based on observation of the students' practical performance. In simulations of practice - typically in role plays the students demonstrate their skills, knowledge and competencies in situations and tasks deriving from their daily work life.

The role plays most often take place in a class room that has somewhat been equipped with arte-facts from real workplaces e.g. kindergartens. There is also a kitchen, enabling the students to demonstrate preparation of e.g. snacks for nursery children in accordance with hygienically standards (competencies 3 and 4). Occasionally, the role play takes place in the gym of the college or outside as in one of the examples below.

The students and the teachers are actors, and the role-plays illustrate, e.g. a sing a song activity with children, an evening meeting for the children's parents or a sport activity.

An example of practical performance inside school: a student shows how they in "her" kindergarten stimulate the children's senses, (part of competency 3): the student has brought along three dish towels, which she places on the floor. On the first dish towel she spreads flour, on the second oatmeal and on the third cornflakes. She asks the students and the teachers to take off their shoes and walk from dish towel to dish towel in order to feel the different structures. One of the teachers decides to play an unwilling child who does not want to participate. The student chooses to let this "child" observe what the other "children" do.

An example of practical performance outside school, (part of competency 2): the student plays a situation from walks in the woods with the children, showing how she - when making birch juice with the children - involves the children in the activity and communicate with them.

According to the teachers the assessment cannot solely be based on observations of the students' performance. The teachers have to make the students transgress the practical demonstrations in order to test the transferability of the students' knowledge and skills. Therefore observation of practical performance will be supplied by various methods that can verbally elicit the students' competences in relation to the subject targets mentioned above. These methods include interviews and group discussions that are conducted by the teachers' systematic use of different types of questions. 


\subsubsection{The teachers ask questions}

In order to check the students' knowing how, knowing that and knowing why as well as the students' consciousness about their social and personal competencies the teachers ask various questions during and after the role play. The questions include:

Questions about the student's knowing how. Through these questions the teacher will check whether the student is able to accomplish specific tasks. E.g.: a student shows a situation where the children should learn to clap their hands to a rhythm and the teacher asks: "How do you make the children clap their hands in tune?" This question refers to competency 2 . The purpose of the questions is also to make the student aware of her precise actions when accomplishing the task and to check the student's ability to articulate her actions.

Questions about the student's knowing that of facts related to the current action or situation. The teacher asks questions which are closely related to factual matters related to the student's performance. If e.g. the student shows a situation from a sing a song activity, the teacher will ask questions like: Where did the activity take place, inside or outside? How many children were involved in the activity? Etc. According to the teachers, these questions serve to reassure the students about the teacher's interest in their performance. The questions are fairly easy to answer, because they refer to the student' practical experiences. Consequently the questions are mainly used in the beginning of the assessment course. Gradually the teachers will concentrate on asking the following type of knowing that questions.

Questions about the student's theoretically-based knowing that. The purpose of these questions is to obtain knowledge about the student's scope of knowledge related to her performance. The student shows, how she prepares fruit for the children. She takes off her rings, before she starts slicing the fruit. "This is in order to avoid bacteria", the student says. The teacher asks: "Can you tell me the hygiene principles for working in a kitchen?" This question is related to the knowledge that is included in parts of the course in hygienics that is part of obtaining e.g. competency 4. Or in the example above about the birch juice the teacher asks questions about the student's biological knowledge, e.g. how the student tells the difference between different kinds of leaves as well as questions that check the student's knowledge about principles for communication with children. This refers to competency no 2 that includes assessment of subject targets within e.g. natural sciences and psychology.

Questions about the student's knowing why. These questions check the student's knowledge about her knowing how, including the student's ability to transfer knowledge from her specific experiences to other situations within the field of child care assistance. The questions typically either check the student's ability to abstract from the specific situation, or the questions check why the student has chosen to perform in a specific way. According to the teachers, the students' ability for abstraction is one of the main challenges in APL, i.e. the student's ability to loosen her experiences from specific practices, in order to generalise the knowing how inherent in her performances. Referring to the sensitivity example above, the teacher asks the student how she might train the children's sensitivity through other means than flour and cornflakes.

The knowing why questions can include instrumental knowledge, e.g. checking the student's knowledge about physiology which is included in competency 9: "Why do you bend in your knees when you lift a child?" And the student may answer: 
"Because bending in your knees has been proven to spare your back." Or the questions can deal with the students' opinions (communicative learning), e.g. "Why do you prefer this children's' book to that one?" These questions are meant for reflection and discussion among the students. Through these discussions the teacher can detect the students' level of argumentation and reflection which is also part of the competencies targets in these VET-programs.

The teachers make surprises or interruptions during the role play (e.g. playing an obnoxious child) in order to check the students' ability for creative thinking and reflection during the performance. The teachers may also do this through questions: What would you do, if a child refuses to wash her hands before lunch? In the birch juice example the student has shown that she is able to communicate with children. The teacher asks how she would communicate if the birch juice activity took place in a special needs' institution for adults.

The teachers' questions are the same questions that they would ask the students at the final exams in the child care assistant program. In these exams the teachers also focus on the students' knowing how, knowing that and knowing why in relation to the target of the subjects. If the students' answers correspond to the criteria for passing the exam the student will obtain credit for the specific subject targets. After having finalized the 10 days assessment course the students may lack a number of subject targets that refer to a number of competencies; in other words, the individual student may have obtained credit for a whole competency and or for parts of the competencies.

\subsubsection{When in doubt}

Occasionally the teachers are in doubt about the reliability or validity of their assessment. The typical way of checking the reliability of the assessment is to compare different persons' assessments of the student's performance. This is accomplished in two ways: the teacher asks her colleagues to focus on the student's performance and verbalizations in relation to specific subject targets and make their assessment. Afterwards the teachers compare and discuss their assessments in order to reach a mutual conclusion. The other way is to make the students assess each other's performances and compare and discuss the students' and the teachers' assessments.

Validity is typically checked by making the student accomplish yet another task in practice that will check the student's performance in relation to a specific subject target. Or the teachers will ask additional questions in order to make sure that the student actually possesses the knowledge. According to the teachers they feel quite confident about their assessments, as long as they can base these on the questions that they would ask during exams.

\subsection{Conclusion}

According to the teachers the combination of role plays and questions about the students' knowing how, knowing that and knowing why enables the teachers to provide opportunities for the students to demonstrate their competences as well as for the teachers to check the students' level of performance in relation to the 11 competencies in the national curriculum. In order to make a precise assessment the teachers have broken the competencies into - for them -recognizable units that refer to targets of specific subjects and practical tasks.

The strength of this way of accomplishing APL is that the students' experiences from specific workplaces can immediately be related to the knowing how, knowing 
that and knowing why of general child care functions. The role plays make it possible to perceive the students' workplaces and experiences from outside in. This eases the translation of the students' local experiences into the standards of national program curriculum.

\subsection{Discussion}

Based on the two examples about school-based assessments the discussion focuses on two issues: the scholastic knowledge versus practical experience and the validity and reliability of the assessment procedures.

\subsection{Scholastic knowledge versus practical experience}

When APL takes place in the school and apart from real workplaces the tendency is that the standards for assessing reflect the school's idea of good practice instead of the workplace-based requirements. The empirical data in this study show that the assessment to a large extent is based on a scholastic perception of what is important to accomplish as a skilled worker.

The assessment is based on the teachers' interpretation of the learning outcome descriptions of competencies in the curricula for the programs. Billett et al., address the same problem:

"On the one hand, the educational institutions awarding RPL towards a qualification requires evidence that matches with their learning outcomes, often expressed as theoretical knowledge (i.e. declarative forms) and, albeit less frequently, if through skills assessments possibly technical knowledge (techne)" (Billett et al., 2014, pp., p. 285).

The VET-college will emphasize and cherish the student's ability to use the professional terms in the way they are used at the college. Similarly the VET-college will focus on whether the student is able to explain a procedure in a theoretical way instead of just showing that they can perform competently. The central question for APL in relation to VET qualifications is: how much knowing that and how much knowing why is needed for skilled level occupations?

As an example we will take the preparation of the dessert, pineapple mousse: when preparing pineapple mousse you should not use raw (un-boiled) pineapple in connection with gelatine, because the gelatine will not coagulate. As a professional gastronome your knowing how about the preparation of pineapple mousse will secure that you always remember to boil the pineapple before mixing it with the gelatine. This knowing-how may have been achieved in various ways. It may have been obtained through reading recipes or through instruction; it may also have been obtained through hard-earned experience from preparing a failed pineapple mouse. The students may have knowledge of how to prepare a pineapple mousse (knowing how).They may also know why they have to boil the pineapple (knowing why). This knowing-why is an integrated part of knowing-how.

So what distinguishes the informally qualified practitioner from the formally qualified practitioner in the example above? The formally qualified practitioner will (in principle) also be able to explain why the gelatine does not coagulate; (the explanation is that the pineapple contains a certain enzyme). The formally skilled professional will (in principle) know that this enzyme is called bromelain (or the pineapple enzyme). Maybe he will (in principle) also know that this enzyme prevents the gelatine from coagulating, and maybe he knows the relevant formula for the chemical process. The general (theoretical) knowledge is desirable as it (in principle) enables 
the professional practitioner to apply his knowledge in other connections where this enzyme occurs. However the fundamental question is how much knowing-why and how profound theoretical knowledge is necessary to be a professional gastronome?

Which forms of knowledge are necessary in order to be able to perform competently in practice? Which forms of knowledge are desirable? The right answer to that question should be based on an analysis of the relation between the formally required competencies in the national curricula and competences used in professional performance within specific occupations.

The data show that in the theoretical test as well as in the observations of the practical assessment situations the teachers emphasize the students' knowing that and knowing why. E.g. one of the teachers in the gastronome program asked the students: why do you have to cook the pineapple'? Likewise in the child care situations, e.g. the situation when the student produces birch juice, the teacher asks the students to name the different kinds of leaves.

\subsection{Is the assessment reliable and valid?}

As described in the case about APL in the child care program, the teachers check the reliability by comparing their assessments of the students' performances. As part of the research project we have studied intersubjective reliability by comparing different teachers' judgments on three variables: 1. possession of knowledge (as measured in written tests); 2. proficiency in the actual performance in the practical assessment; and 3. the amount and content of the training that the students need in order to qualify for the skilled level. The teachers were asked to make their validation independently, and the teachers' judgments were afterwards compared in pairs, five pairs in all. On all three variables the teachers agreed on averagely three out of four items. After a brief discussion in pairs, the teachers were able to reach a compromise. The results correspond to the findings in a study of Stenlund. She concludes that

"the intrarator reliability study reveals a higher agreement level than the interrator reliability study" (Stenlund, 2013, p. 545).

The results from the study tell us that the assessments made by the teachers have a high predictive validity. It means that the students are actually able to pass their exam or journey man's test after they have completed the training according to their individual educational plans. In the child care assistant assessment case the teachers ask the students the same questions in the assessment as they would do in the exams.

Has the assessment high concept validity? Do the teachers assess the students in relation to each of the actual competencies required? Or are their assessments based on general impressions of what they think skilled workers should be able to accomplish? And are the teachers' impressions based on the content of the training programs rather than on a definition and an understanding of the specific competencies required? The study shows that the teachers are not able to directly connect the competencies and the assessment instruments. In the interviews with some of the teachers it became clear that they base their judgment on general impressions and not directly on the prescribed competencies.

Choosing the right practical tasks or situations is an important part of securing validity. In the gastronome program the menus that the students are asked to prepare are not neutral in relation to the student's prior learning; the student may e.g. have worked in an Italian restaurant and has no experience with the Nordic cuisine. Or the student may have experience with la carte menus but not with party orderings. 
An issue for further research is whether the competencies in the current VET-program can be more or less suitable for school-based assessment, the distinction being between production and service. The study deals about two different VET programs about production (gastronome) respectively service (child care assistant).

Assessing whether you may function as a skilled worker within production, e.g. carpenter, blacksmith, painter or gastronome may in principle be conducted by letting the student accomplish the real task, e.g. constructing a roof, fold a metal object, paint and wallpaper a room, or prepare a meal. The students are able to perform in the same way as they would do in the workplace. Even though the assessment takes place in the VET college it is possible to test the students' competences in relation to the practical tasks in the college workshops.

In the service professions, such as child care assistant, a realistic and everyday life situation cannot be established at the VET-college. The teachers will have to simulate real practices e.g. in role plays, and the students are actors playing child care assistants. A question for further research could be: is the validity of schoolbased assessment in relation to production sectors higher than in relation to service sectors?

The study shows that a valid assessment of the competences requires the use of several methods that supplement each other, e.g.: interviews, an evaluation of professional knowledge, a test on whether the students can apply knowledge in practice and practical demonstration, including accomplishing specific tasks. Accomplishing specific tasks gives an impression of the student's confidence, routine, and skills. Through the specific tasks the student can demonstrate his use of knowledge and skills, i.e. his knowing how. A significant part of the competence is tacit knowledge in the sense that the student is not able to or has difficulties in articulating how and why he/she performs in specific ways. Experiences from the project show that the practical demonstrations are particularly useful for eliciting the students' tacit knowledge.

The methods can be supplemented with other methods for assessing prior learning. Wihak and Wong discuss different methods in a Canadian university context and conclude that

"the predominant methods to assess learning is the paper-based portfolio" (Wihak and Wong, 2011, p. 317).

Fejes and Andersson use the same procedure in a training program for nurses. The nurses made

"a self-assessment to estimate their own knowledge in a certain area" (Fejes and Andersson, 2009, p. 47).

Pokorny suggests that a combination of personal portfolios and dialog improves the quality of the assessment process and leaves the students with a more satisfying picture of the assessment process (Pokorny, 2013). In a further development of the combination of methods self-assessment should be tried out.

\section{Conclusion}

In the article examples of school-based assessment have been exemplified and discussed. The study shows that the combination of several APL methods makes it possible both to elicit the students' tacit knowledge through observing their practical 
performance and to assess the students' scope and level of knowing how, knowing that and knowing why.

The study also shows that in school-based APL, being isolated from practice in real workplaces, the tendency is that the assessment will be based on the school's idea of good practice within the vocation rather than on the actual tasks and demands in the workplaces. There is a tendency too that the teachers put priority to knowing that and knowing why rather than to knowing how.

Based on the empirical data two issues for discussion have been raised, the first issue concerning the teachers' interpretation of the competencies outlined in the national curricula of the programs. The assessment system (and the assessors) must be aware of what kind of knowledge is needed to be a professional practitioner in skilled occupations and to be able to tell the differences between school-based course plans traditions and the competencies needed in the workplaces.

The second issue concerns the validity and reliability of the assessment procedures. The study shows that the teachers aim at strengthening validity and reliability by combining various methods and by comparing their individual assessments. The study has pointed to differences in APL within the production VET programs respectively the service VET programs, proposing that further development and research into APL may focus on whether there is a need to adjust the assessment procedures specifically to the particularities of the individual program.

A third issue concerns the assessors' (in this study the teachers') competences. As mentioned in other studies the ability to make correct and valid assessment requires specific competences (Halttunen and Koivisto, 2014; Hamer, 2010; van Berkel, 2014). The assessors (the teachers) should be able to transform knowledge and observed performances into competencies. They should have knowledge about the specific job functions and tasks within the specific occupation as well as knowledge about the contents of the curriculum of the VET-program. And they should be able to transform the results of the assessment process into an adequate training program based on the assessment results. It seems reasonable to conclude that a fair and a valid assessment process require specific competences.

In the article it has not been argued that school-based assessment is better or worse that workplace-based assessment. The study shows that practical based competences can be assessed within the educational system with high validity, however under the following specific conditions:

- The required competences should be well defined, precise and operative.

- The educational system should bel aware of securing a balance between knowing how, knowing that and knowing why, and that knowing why can be demonstrated in different ways

- The assessors, teachers, should possess specific assessment competences.

The results from this study indicate that further research and more practical experiences are needed to highlight the crucial epistemological question: to what extent can practical knowledge be transformed into credits not only for the practical performance parts of the competencies, but also for the knowledge inherent in the competencies? 


\section{References}

Aarkrog, V. \& Wahlgren, B. (2013). Challenges in relation to assessment of prior learning. Retrieved from www.nck.au.dk website.

Andersen, M. \& Laugesen, C. (2012). Recognition of Prior Learning within Formal Adult Education in Denmark. PLAIO - Prior Learning Assesment 1(2).

Andersson, P. (2006). Different faces and functions of RPL: an assessment perspective. In P. Andersson, Harris, J. (Ed.), Re-theorising the Recognition of Prior Leraning. Leicester: National Institute of Adult Continuing Education.

Andersson, P.; Fejes, A. \& Sandberg, F. (2013). Introducing research on recognition of prior learning. International Journal of Lifelong Education, 32(4), 405411.

Andersson, P. \& Harris, J. (2006). Re-theorising the Recognition of Prior Learning. Leicester: National Institute of Adult Continuing Education (NIACE).

Andersson, P. \& Stenlund, T. (2012). Nordisk forskning och exempel på validering (Nordic research on validation of prior learning). Oslo: NVL/VOX.

Billett, S.; Bound, H. \& Lin, M. (2014). Recognising and Certyfying Workers' Knowledge: Policies, Frameworks and Practices in Prospect: Perspectives from Two Countries. In T. Halttunen, M. Koivisto \& S. Billett (Eds.), Promoting, Assessing, Recognizing and Certifying Lifelong Learning. Dortrecht: Springer.

Bohlinger, S. (2013). Qualification frameworks and learning outcomes: challenges for Europe's lifelong learning area. Journal of Education and Work, 25(3), 279-297.

CEDEFOP (2009). European guidelines for validating non-formal and informal learning. Luxenbourg: Office for Official Publications of the European Communities.

Colardyn, D. \& Bjørnåvold, J. (2004). Validation of formal, non-formal and informal learning: policy and practices in EU member states. European Journal of Education, 39(1).

Cooper, L. \& Harris, J. (2013). Recognition of prior learning: exploring the 'knowledge question'. International Journal of Lifelong Education, 32(4), 447-463.

Diedrich, A. (2013a). Translating validation of prior learning in practice. International Journal of Lifelong Education, 32(4), 548-570.

Diedrich, A. (2013b). 'Who's giving us the answers'? Interpreters and the validation of prior foreign learning. International Journal of Lifelong Education, 32(2), 230-246.

European Council (2008). Recommendation of the European Parliament and the Council of 23 April 2008 on the establishment of the European Qualifications Framework for lilelong learning, Annex 1.

European Council (2012). Council Recomendation on the validation of non-formal and informal learning of 20 december 2012. Brussel: European Council.

Fejes, A. \& Andersson, P. (2009). Recognising Prior Learning: Understanding the Relation Among Experiences, Learning and Recognition from a Constructivist Perspective. Vocation and Learning, 2(1), 37-55.

Halttunen, T. \& Koivisto, M. (2014). Professionalisation of Supervisors and RPL. In T. Halttunen, M. Koivisto \& S. Billet (Eds.), Promoting, Assessing, Recognizing and Certifying Lifelong Learning. Dordrecht: Springer. 
Halttunen, T.; Koivisto, M. \& Billett, S. (Eds.) (2014). Promoting, Assessing, Recognizing and Certifying Lifelong Learning - International Perspectives and Practices. Dordrecht Heidelberg New York London: Springer.

Hamer, J. (2010). Recognition of prior learning - Normative assessment or coconstruction of preferred identities? Australian Journal of Adult Learning, 50(1).

Harris, J.; Breier, M. \& Wihak, C. (Eds.) (2011). Researching the Recognition of Prior Learning - International perspectives. Leicester: International Institute of Adult Continuing Education (niace).

Pokorny, H. (2011). England: Accreditation of Prior Experientel Learning (APEL) research in higher education. In J. Harris, M. Breier \& C. Wihak (Eds.), Researching the Recognition of Prior Learning. Leicester: National Institute of Adult Continuing Education (niace).

Pokorny, H. (2013). Portfolios and meaning-making in the assessment of prior learning. International Journal of Lifelong Education, 32(4), 518-534. doi: 10.1080/02601370.2013.778076.

Polanyi, M. (1966). The Tacit Dimension. Gloucester, Mass.: Peter Smith.

Ryle, G. (1949). The Concept of Mind. London: Hutchinson.

Starr-Glass, D. (2012). Partial Alignment and Sustained Tension: Validity, Methaphor and Prior Learning Assessment. PLAIO - Prior Learning Assesment, $1(2)$.

Stenlund, T. (2011). As valid as it can be? Assessment of prior learning in higher education. Umeå University, Umeå.

Stenlund, T. (2013). Agreement in assessment of prior learning related to higher education: an examinsation of interrater and intrarater reliability. International Journal of Lifelong Education, 32(4), 535-547.

van Berkel, A. (2014). Secuering Assessors' Professionalism: Meeting Assessor Requirements for the Purpose of Performing High-Quality (RPL) Assessments. In T. Halttunen, M. Koivisto \& S. Billet (Eds.), Promoting, Assessing, Recognizing and Certifying Lifelong Learning. Dordrecht: Springer.

Watkins, K. E.; Marsick, V. J. \& Álava, N. F. (2014). Evaluation Informal Learning in the Workplace. In T. Halttunen, M. Koivisto \& S. Billet (Eds.), Promoting, Assessing, Recognizing and Certifying Lifelong Learning. Dordrecht: Springer.

Wihak, C. \& Wong, A. (2011). Research into Prior Learning Assessment and Recognition (PLAR) in university adult education programmes in Canada. In J. Harris, M. Breier \& C. Wihak (Eds.), Researching the Recognition of Prior Learning. Leiceister: National Institute of Adult Continuing Education (niace). 
